S International Journal of Agriculture and Wildife
http://dergipark.org.tr/ijaws

Research Article

\title{
Genetic variability of Grapevine Leafroll-Associated Virus-1,2,3,4 Infecting Vineyards in Tokat Province of Turkey ${ }^{* *}$
}

\author{
Kübra Sarıtaş (D) , Şerife Topkaya* \\ 'Department of Plant Protection, Faculty of Agriculture, Tokat Gaziosmanpaşa University, Tokat, Turkey
}

Received: 03.08.2021

Accepted: 01.11.2021

\section{Keywords:}

Grapevine leafroll disease, Vitis vinifera, virus, RT-PCR, Tokat

*Corresponding author serife.topkaya@gop.edu.tr

Abstract. Grapevine leafroll disease (GLRD) is one of the most important viral diseases of grapevine worldwide. The aim of this study was to investigate the prevelance of Grapevine leafroll associated virus-1 (GLRaV-1), Grapevine leafroll-associated virus-2 (GLRaV-2), Grapevine leafroll-associated virus3 (GLRaV-3), Grapevine leafroll-associated virus 4 (GLRaV-4), and Grapevine leafroll-associated virus-9 (GLRaV-9) in Tokat province of Turkey. In 2018, leaf samples and one-year-old shoots of plants, showing virus-like symptoms, were collected from different vineyards in Central, Erbaa, Niksar, and Pazar districts of Tokat province. Totally 197 samples were obtained and tested molecularly using twostep polymerase chain reaction (PCR) by using virus-specific primers for GLRaV-1, GLRaV-2, GLRaV-3, GLRaV-4) and GLRaV-9. At least 106 (53.80\%) samples were found to be infected showed single or multiple infections. The 103 (52.28\%) samples resulted in positive with GLRaV-1 while the infection rates were $\% 5.18$ for GLRaV-3 with 10 samples, \%2.53 for GLRaV-4 with 5 samples, \%1.03 for GLRaV2 and GLRaV-9 with 2 samples, respectively. The amplified PCR products of GLRaV-1, GLRaV-2 and GLRaV-3 were sequenced, aligned with MEGAX, and analyzed in BLAST for multiple comparisons of other isolates in the GenBank. Sequence analysis of viruses showed $94-96 \%, 96-99 \%$ and, $99-100 \%$ nucleotide identity with references isolates in the GenBank for GLRaV-1, GLRaV-2, and UO3-3 isolate of GLRaV-3 respectively.
\end{abstract}

\section{Tokat ili Bağlarda Grapevine leafroll-associated virus -1,2,3,4'ün yaygınlığı ve Genetik Değişkenliği}

\section{Anahtar kelimeler:}

Asma yaprak kıvırcıklı̆̆ı hastalığı, Vitis vinifera, virus, RT-PCR, Tokat

\begin{abstract}
Özet. Asma yaprak kıvırcıklığı hastalığı (GLRD), dünya çapında asmanın en önemli viral hastalıklarından biridir. Bu çalışma, Grapevine leafroll associated virus -1 (GLRaV-1), Grapevine leafroll associated virus -2 (GLRaV-2), Grapevine leafroll associated virus -3 (GLRaV-3), Grapevine leafrollassociated virus 4 (GLRaV-4), ve Grapevine leafroll-associated virus-9 (GLRaV-9) etmenlerinin yaygınlığının araştırıması amacıyla yapılmıştır. Bunun için Tokat ili Merkez, Erbaa, Niksar ve Pazar ilçelerindeki farklı bağ alanlarından virüs benzeri belirti gösteren asmalardan yaprak örnekleri ve bir yıllık bitki sürgünleri toplanmıştır. Surveyde elde edilen toplam 197 örnek GLRaV-1, GLRaV-2, GLRaV3, GLRaV-4) ve GLRaV-9 etmenlerine özgü primerler ile iki aşamalı polimeraz zincir reaksiyonu (PCR) kullanılarak moleküler olarak test edilmiştir. 197 örnekten 106'sı (\%53.80) bu virüslerle tekli veya çoklu enfeksiyon tespit edilmiştir. 103 (\%52,28) örnek GLRaV-1 ile pozitif sonuçlanırken, enfeksiyon oranları 10 örnekle GLRaV-3 için \%5,18, GLRaV-4 için 5 örnekle \%2,53, GLRaV-2 ve GLRaV-9 için \%1,03 olarak belirlenmiştir. GLRaV-1, GLRaV-2 ve GLRaV-3'ün pozitif PCR ürünleri çift yönlü sekans analizinden sonra MEGAX ile GenBank'taki referans diğer izolatlarla karşılaştııılması yapılmıştır. GLRaV-1 izolatlarının sekans analizine göre GenBank'taki referans izolatlarla \%94-96, GLRaV-2 izolatları \%96-99 ve GLRaV-3'ün UO3-3 izolatı \%99-100 nükleotid benzerliği göstermiştir.
\end{abstract}




\section{INTRODUCTION}

Turkey is located within the most suitable climate zone of the world for viticulture. Thus, the country has a quite old history of viticulture. According to 2017 statistics, the world vineyard area was 6931353 ha with an annual grape production of 74276583 tons (FAO, 2017). According to 2017 FAOSTAT data, Spain has the greatest vineyard area and China is the greatest grape producer in the world. Among the viticulture practicing countries, Turkey has 5 th place in vineyard area and 6th place in grape production (FAO, 2017). The quantity of production; 1945262 tons were table grapes, 1524091 tons were for dried grapes and 463647 tons were for wine production.Turkey also is the world's largest producer for dried grapes constituting $28 \%$ of global production in 2014 (FAO, 2016).

Viticulture is an important agricultural activity in Turkey both for fresh consumption and wine production. While some of the annual fresh production is consumed as table grapes, some others are consumed either seedless or seeded raisins. Grape export constitutes a significant revenue for the country's economy. Besides grape, the leaf is another product obtained from vineyards. The demand for fresh and brined grape leaves is always increasing. Most of the vineyards in the province were established with this grape cultivar. More than 80 viruses and five viroids have been identified in Vitis spp., making grapevine the most virus-infected agricultural commodity known to date (Martelli, 2017). Grapevine leafroll disease (GLRD) is the most widespread and economically destructive disease among the grapevine virus diseases. GLRD are represented by the species GLRaV-1, $-2,-3$ and -4 and recently, GLRaV-5, -6, -7, -9, GLRaVPr, GLRaV-De, and GLRaV-Car were recognized as strains of GLRaV-4 (Martelli et al., 2012; Martelli, 2014). All these viruses belong to the genus Ampelovirus except for GLRaV-2, which is in the genus Closterovirus, and GLRaV-7, which is in the tentative genus Velarivirus (Al Rwahnih et al., 2011).

Several studies have been conducted to determine the problems caused by GLRaV's in Turkish vineyards production areas. Gursoy (1991) reported that GLRaV-1 and GLRaV-3 were common in vineyards of Tekirdağ, Yalova and Manisa provinces; Buzkan et al. (2012) conducted a survey in Turkish vineyards and noted that GLRaV1 and GLRaV-3 were generally found in the vineyard areas of the Eastern Mediterranean (Kahramanmaraş, Mersin, Hatay) and Southeast Anatolia (Adıyaman, Gaziantep, Kilis, Diyarbakır and Şanlıurfa) regions of Turkey. Kaya and Erilmez (2014) reported the existence of GLRaV-1, -2, -3, -4 and -9 in vineyards in Izmir, Manisa, Çanakkale and Denizli provinces; Ince and Yavuz (2015) found GLRaV-1, -2, -3, -4, -6 and -9 in Eastern Mediterranean Region by serologically. Onder (2016) identified GLRaV-9, GLRaV-Pr and GLRaV-De viruses for the first time in Izmir, Aydın, Denizli, Manisa and Uşak provinces. Omeroğlu (2016) identified GLRaV-1, $-2,-3$ and -5 in Tekirdağ province, Sarköy and Marmara Ereğlisi districts. Yakar (2017) showed the presence of GLRaV-2 in the Eastern Mediterranean and Southeastern Anatolia regions.

Tokat province stands out especially with the production of pickled leaves. Karadeniz et al. (2018) conducted some serological tests in Tokat province and detected GLRaV-1 in the survey area. The main goal of this study, to understand the molecular structure of other GLRaV's by sequencing and comparing the related data with reference sequences from Genbank. This study was conducted to identify important and emerging grapevine viruses (GLRaV-1, GLRaV-2, GLRaV-3, GLRaV-4 and GLRaV-9) through molecular methods in important grapevine growing fields of Tokat province. This study will provide a scope for further research in grapevine infecting viruses based molecular studies.

\section{MATERIAL AND METHOD}

\section{Plant Material and RNA Extraction}

Grapevine leaves and annual shoot samples were collected from plants showing virus infection symptoms in the grapevine from the Centre, Erbaa, Niksar and Pazar districts of Tokat during the autumn in 2018 growing period. In total 197 samples, cvs Sultani, Narince, which is the local variety and cv Syrah, were collected and stored at $20^{\circ} \mathrm{C}$ until use. Total nucleic acids were extracted from each sample using the main veins of the leaf, petiole, stalks and phloem scrapings of annual shoots. RNA isolation was made according to Li et al. (2008)'s protocol with some addititiolan modifications.

\section{Molecular Studies}

\section{Complementary DNA (cDNA) Synthesis and PCR}

Complementary DNA (CDNA) synthesis was performed in a $10 \mu \mathrm{l}$ total volume and used as a template for PCR analysis. The $5 \mu \mathrm{l}$ of extracted RNA was used as a template and added to a PCR tube and incubated $5 \mathrm{~min}$ at $65^{\circ} \mathrm{C}$. 
Then the reaction mix containing $1 \mu \mathrm{l} 10 \mathrm{X}$ reaction buffer (Wizscript), $0.5 \mu \mathrm{l} 20 \mathrm{X} \mathrm{dNTP}(2.5 \mathrm{mM}), 1 \mu \mathrm{l}$ random hexamer primer, $0.5 \mu \mathrm{l}$ reverse transcriptase enzyme (Wizscript), $0.25 \mu \mathrm{l}$ RNAse inhibitor, 1.75 of nuclease-free water added to the tube. RT reaction was performed with a 10 min incubation at $25^{\circ} \mathrm{C}$, followed by at $37^{\circ} \mathrm{C}$ for two $\mathrm{h}$ and $85^{\circ} \mathrm{C}$ for $5 \mathrm{~min}$.

The PCR was performed with $2.5 \mu \mathrm{L}$ of CDNA, $0.2 \mu \mathrm{L}$ of $25 \mathrm{mM}$ dNTPs, $2 \mu \mathrm{L}$ of $25 \mathrm{mM} \mathrm{MgCl}, 5 \mu \mathrm{L}$ of $5 x$ green reaction buffer and $0.5 \mu \mathrm{L}$ of $10 \mu \mathrm{M}$ of each specific primers (Table 1) adding with $0.25 \mu \mathrm{L}$ of 5 units $\mu \mathrm{L}^{-1}$ Taq DNA

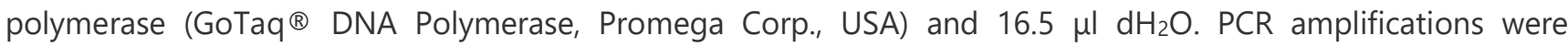
conducted according to references in at Table 1. The PCR products were analyzed by electrophoresis in $1.2 \%$ agarose gel containing $10 \mathrm{mg} / \mathrm{ml}$ ethidium bromide and visualized under UV light.

Table 1. The primers used in this study.

Çizelge 1. Çalışmada kullanılan primerler.

\begin{tabular}{|c|c|c|c|}
\hline Primer & Primer sequence & Long & References \\
\hline GLRaV 1-F & CGACCCCTTTATTGTTTGAGTATG & \multirow{2}{*}{$401 \mathrm{bp}$} & \multirow{2}{*}{ Martin et al., 2005} \\
\hline GLRaV 1-R & GTTACGGCCCTTTGTTTATTATGG & & \\
\hline GLRaV 2-F & ATAATTCGGCGTACATCCCCACTT & \multirow{2}{*}{332 bp } & \multirow{2}{*}{ Martin et al., 2005} \\
\hline GLRaV 2-R & GCCCTCCGCGCAACTAATGACAG & & \\
\hline GLRaV 3- LR3-8504V & ATGGCATTTGAACTGAAATT & \multirow{2}{*}{$940 \mathrm{bp}$} & \multirow{2}{*}{ Ling et al., 2004} \\
\hline GLRaV 3- LR3-9445C & СTACTTCTTTTGCAATAGTT & & \\
\hline GLRaV 4up & CCAACTGTCGTGGGTATAAGGAAT & \multirow{2}{*}{243 bp } & \multirow{2}{*}{ Maliogka et al., 2008} \\
\hline GLRaV 4do & CCCAGACACCGGTCCTATACTIA & & \\
\hline GLRaV 9-F & CGGCATAAGAAAAGATGGCAC & \multirow{2}{*}{$393 \mathrm{bp}$} & \multirow{2}{*}{ Alkowni et al., 2004} \\
\hline GLRaV 9-R & TCATTCACCACTGCTTTGAAC & & \\
\hline
\end{tabular}

\section{Sequencing and Phylogenetic Analysis}

The PCR products were sequenced in two directions (forward and reverse) with Sanger technology. The obtained nucleotide sequences were analyzed by the program Molecular Evolutionary Genetics Analysis using neighbor-joining method (NJ methods) (software MEGAX (Kumar et al., 2018). The Bootstrap analysis was performed with 1000 replications.

\section{RESULTS AND DISCUSSION}

\section{Symptoms}

A total of 197 vine samples were collected from Tokat Central, Erbaa, Niksar and Pazar towns in 2018. Symptoms on collected samples included; mosaic, yellowing, green veins-yellowing in interveinal, chlorosis in veins-green color formation in interveinal, color desaturation in veins, vein banding, shape disorders, reddening, , necrotic spots, brown spots, mottling, swells, leaf curling inside, increase in leaf teeth, fan-like leaf formation, decrease in a number of clusters and cluster size, decrease in fruit set, irregular (small-large) berry formation, irregular coloration, recess in development and general dwarfness (Figure 1).

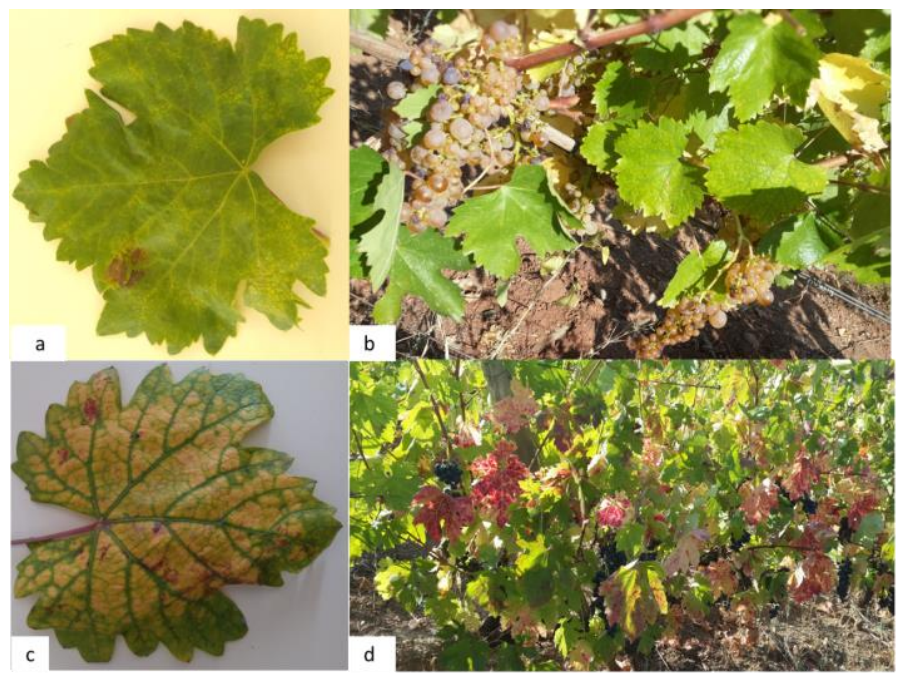

Figure 1. a)Mosaic, irregular (small-large) berry formation, chlorosis in veins-green color formation in interveinal, reddening. Şekil 1. a) Mozaik b) Irili ufaklı tane oluşumu c) Damar aralarında sararma d) Kırmızılaşma. 


\section{RT-PCR Results}

A total of 197 vine samples were subjected to RT-PCR analysis with a virus or strain-specific primers for diagnosis of GLRaV-1, GLRaV-2, GLRaV-3, GLRaV-4 viruses and GLRaV-9 strain. According to RT-PCR results, virus infection was identified in 106 samples of 197 samples. Of the total samples, 103 (52.28\%) were identified as GLRaV-1, 10 (5.18\%) with GLRaV-3, 5 (2.53\%) with GLRaV-4, 2 (1.03\%) with GLRaV-2 and 2 (1.01\%) with GLRaV-9 strain infected (Table 2). GLRaV-1 was the most common virus in samples collected from Central and the other parts of Tokat province and it was followed by GLRaV-3. The least infecting rates showed viruses were identified as GLRaV-2 and GLRaV-9 strain.

Table 2. Town-based distribution of identified viruses.

Çizelge 2. Tespit edilen virüslerin ilçelere göre dağıımı.

\begin{tabular}{|c|c|c|c|c|c|c|c|}
\hline Town & $\begin{array}{l}\text { Number of } \\
\text { tested } \\
\text { sample }\end{array}$ & $\begin{array}{l}\text { Number of } \\
\text { Infected } \\
\text { Plants }\end{array}$ & GLRaV-1 & GLRaV-2 & GLRaV-3 & GLRaV-4 & $\begin{array}{l}\text { GLRaV-9 } \\
\text { strain }\end{array}$ \\
\hline Central & 47 & 31 & 30 & - & 1 & 1 & - \\
\hline Erbaa & 48 & 17 & 17 & - & - & - & - \\
\hline Niksar & 21 & 14 & 14 & 1 & - & - & - \\
\hline Pazar & 81 & 44 & 42 & 1 & 9 & 4 & 2 \\
\hline Total & 197 & 106 & 103 & 2 & 10 & 5 & 2 \\
\hline
\end{tabular}

The symptoms of viruses diagnosed with RT-PCR tests were compared and symptoms observed in GLRaV-1infected plants included mosaic, vein banding, and reddening, symptoms in GLRaV-3-infected plants included reddening, the symptoms in infected with mixed GLRaV-1 and GLRaV-2 included reddening in leaves.

\section{Phylogenetic Analysis}

Sequence information of five isolates infected with GLRaV-1, one isolate infected with GLRaV-2 and one isolate infected with GLRaV-3 were used for phylonetic analysis. At the end of sequencing anlysis, five samples of GLRaV1 and one GLRaV-2 sample yielded bilateral outcome and one sample of GLRaV-3 yielded reverse outcome and tests were done with these data.

Among RT-PCR positive resulted samples by using specific primers for coat protein duplicate 2 (CPd2) for GLRaV-1, five isolates (UO1-3, UO2-2, UO7-9, Ka3-2, Ka1-3) were selected and sequenced. Sequence data was deposited in the Genbank under the accession numbers MN871916-MN871920. According to phylogenetic analysis, Ka1-3 isolate exhibited similar branching with Australian isolate (AF195822) and the other four isolates showed close similarity with Chilean isolate and generated a separate branching (Figure 2). Five Turkey isolates were grouped into Group 2 with a reference isolate AF195822.

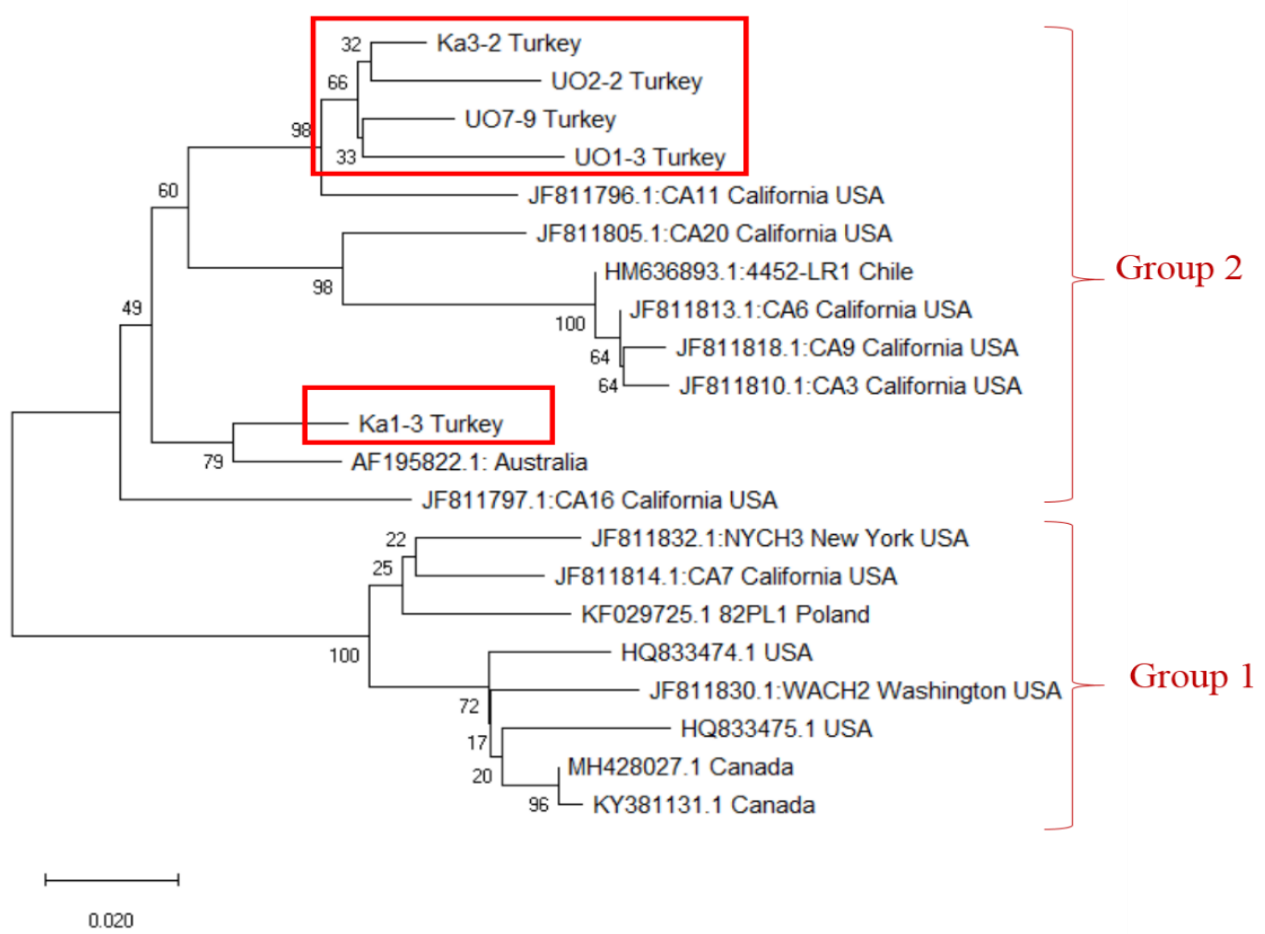

Figure 2. Phylogenetic tree obtained with GLRaV-1. The sequences obtained in this study are shown in the red boxes. Şekil 2. GLRaV-1 ile elde edilen filogenetik ağaç. Bu çalışmada elde edilen izolatlar kırmızı kare ile işaretlenmiştir. 
For the CPd2 analysis, 5 isolates from Turkey and reference isolates from GenBank were used. According to phylogenetic analyses of $5 \mathrm{CPd} 2$ gene sequences of GLRaV-1, two main groups were obtained (Figure 2 ) as before reported by Alabi et al (2011) and Elçi (2019) and the Turkish isolates were clustered into Group 2 and clustered different cluster in this group. California isolates from the USA (CA11) were found highly similar to Turkish isolates with high bootstrap values. The GenBank sequences obtained from Poland, some isolates from California, Washington and Canada were clustered into Group 1 but none of the Turkish isolates were clustered there (Figure 2).

The 327 bp-long nucleotide obtained with heat shock protein (hsp70h gene region) of GLRaV-2 were compared with the isolates recorded in the GenBank (Figure 3). The G2-4 GLRaV-2 isolate showed 98-99\% similarity with the isolates from Canada (KY381141), USA (EU760780), and China and was placed over the same branch in the phylogenetic tree. So far, for GLRaV-2, six variants were reported by researchers, the variant 'Pinot Noir (PN), 93/955, H4, BD, RG and PV20 (Beuve et al., 2007; Bertazzon et al., 2010). The groups PN and H4 are more common groups. The RG group contains isolates provided from the variety Red Globe obtained in California. The PV20, BD and 93/955 groups were less represented up to now. In our study two GLRaV-2 isolates founded in the surveying area and one isolate (G2-4) was sequenced. According to sequence and phylogenetic analysis results, G2-4 isolates grouped with PN isolates. So far, the PN variant was reported to be most widespread worldwide and associated with leafroll symptoms and graft incompatibility on grapevines. More studies are required to understand the presence of other genetic variants of GLRaV-2 in Tokat vineyards.

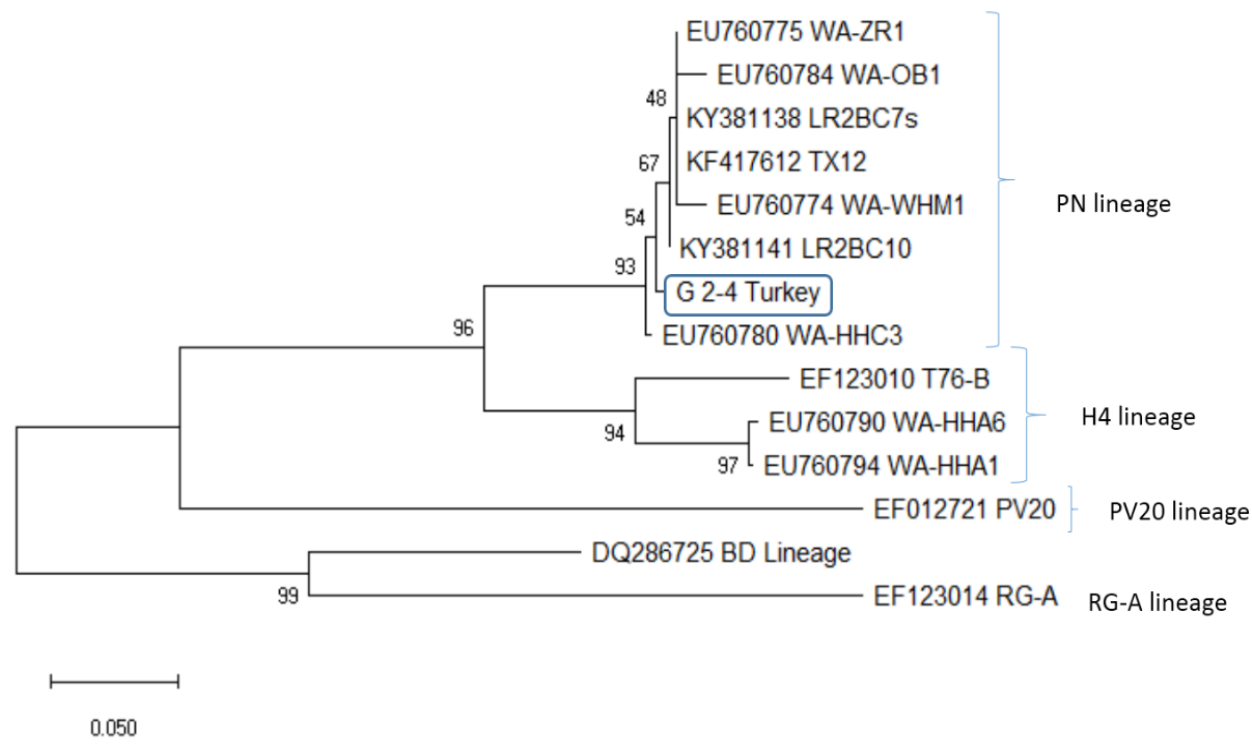

Figure 3: Phylogenetic tree for G2-4 isolate infected with GLRaV-2. The sequences obtained in this study are shown in the blue box.

Şekil 3. GLRaV-2 ile enfekteli G2-4 izolatına ait filogenetik ağaç. Bu çalışmada elde edilen izolatlar mavi kare ile işaretlenmiştir.

The 505 bp-long nucleotides belong to coat protein region of GLRaV-3 was compared with the isolates recorded in the GenBank (Figure 4) and UO3-3 isolate showed 100\% similarity with the isolates from China, Brazil, Hungary, and the USA and placed over the same branch in the phylogenetic tree. The isolate exhibited $99 \%$ identity with two isolates from Portugal and China and, a separate branching in the phylogenetic tree. When compared the nucleotide sequence of UO3-3, only one base was different from references isolates. However, such one base difference did not generate a difference in the protein. The CP sequences of UO3-3 revealed restricted nucleotide and amino acid divergences among reference isolates, suggesting low variability among the analyzed isolates. The nucleotide sequence of Turkish isolates of UO3-3 GLRaV clustered together isolates from Hungary, USA and Brazil (Figure 3), in group I as defined by Maree et al. (2015) and Moura et al. (2018) and showed nucleotide and amino acid identities $100 \%$. 


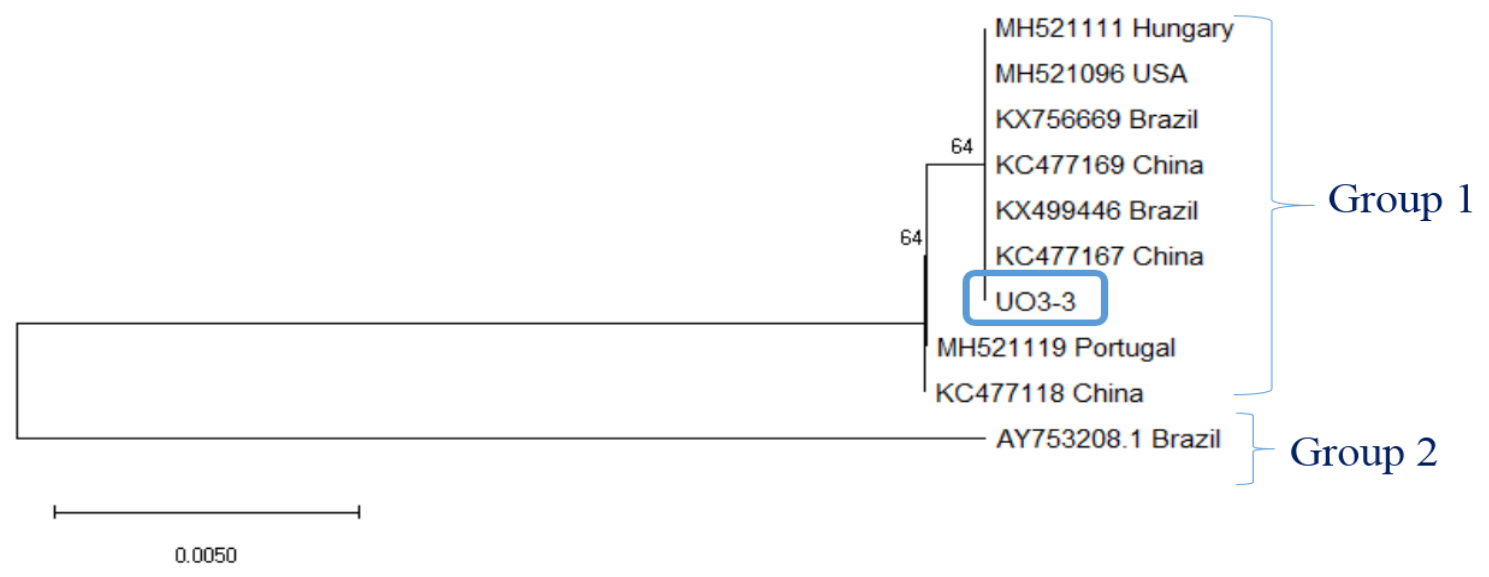

Figure 4. Phylogenetic tree for UO3-3 isolate infected with GLRaV-3. The sequences obtained in this study are shown in the blue box.

Şekil 4. GLRaV-3 ile enfekteli UO3-3 izolatına ait filogenetik ağaç. Bu çalışmada elde edilen izolatlar mavi kare ile işaretlenmiştir.

\section{DISCUSSION AND CONCLUSION}

Viral diseases influence culture plants at different levels and cause yield losses. Such a loose continues every year in perennial species like grapevines and can emerge even 10-20 years after planting. Perennial plant species can stay infected throughout the entire lifetime and serve as a source of inoculum. Yield loses in virus-infected trees may vary from season to season. Non-yielding trees with severe infections or in cases with the fast spread of the disease, trees may be cut down. Besides instant loses, continuous economic losses may also be generated until the newly planted trees reach to the full-yield stage.

Viruses result in serious yield losses in cultural plants. Contrary to the other pathogens in plants, there are not any direct control methods for viruses. Since the majority of the methods used in control of viral diseases aim at protection, there is a need for reliable and precise methods or techniques for the diagnosis of viruses. Besides serological methods, molecular methods are also employed in the diagnosis of viral diseases. Since these methods are versatile methods, they yield reliable outcomes (Erkan et al., 2011). Viruses and viroids result in a recess in growth and development, shape disorders, color changes in leaves and yield losses. The most significant viral disease agents of grapevines result in short internodes and leaf curling (Martelli, 2014). GLRaVs generally result in curling, irregular fruit set, general dwarfness and recessed growth in grapevines. They also result in 10-70\% yield losses and reduce fruit sugar content. These viruses reduce grafting performance and plant rooting ability and reported in Turkish vineyards (Turkmen, 2014; Onder et al., 2016).

To date, there are several serological studies on GLRaV-1 incidence in grapevine growing areas of Turkey. Ince and Yavuz (2015) diagnosed GLRaV-1 in Eastern Anatolia region through DAS-ELISA tests; Omeroglu (2016) diagnosed GLRaV-1 and GLRaV-3 as the most common viruses in Central, Sarkoy and Marmara Ereglisi towns of Tekirdag province. The other studies conducted for the diagnosis of GLRaV agents revealed that GLRaV-1 and GLRaV-3 were the most common leaf curling agents in grapevines. In the present study, GLRaV-1 and GLRaV-3 were also diagnosed as the most common viral disease agents in vineyards of Tokat province. Turkmen (2014) conducted DAS-ELISA tests in vineyards of Ankara, Manisa, Izmir, Denizli, Nevsehir, Elazıg, Canakkale, Edirne, Tekirdag and Kirklareli provinces and reported GLRaV 4-9 viruses as the most common ones, but GLRaV-4 and GLRaV-9 strain were not common in Tokat province. In another study conducted in Tokat province, Karadeniz et. al. (2018) used a serological method of DAS-ELISA and diagnosed GLRaV-1 (9\%) as the most common disease agent.

In the present study, the molecular method of RT-PCR was used, and GLRaV-1 was diagnosed in more than half of the samples (52\%) collected from different districts of Tokat province.. It was observed that GLRaV-3 was also common in vineyards of Tokat province. With this study, GLRaV-2, GLRaV-3 and GLRaV-9 strain viral disease agents were reported for the first time in Tokat province and GLRaV-2 and GLRaV-9 strain were molecularly reported for the first time in Turkey. In this study, GLRaV-2 and GLRaV-9 strain were the least common disease agents. 
Literature reviews revealed that this study was the first one conducted at a molecular level for detection of vine viruses in Tokat province. Within the scope of this study, the existence of GLRaV-1, GLRaV-2, GLRaV-3, GLRaV- 4 and GLRaV-9 strain viral disease agents was investigated in vineyards of Tokat Central, Erbaa, Niksar and Pazar towns. Present tests revealed that 106 (53.80\%) of 197 samples had one or more the investigated disease agents. GLRaV-1 was diagnosed as the most common virus in vineyards of Tokat province and it was followed by GLRaV-3. Among the mixed infections, GLRaV-1 + GLRaV-3 was the most common one.

In this study, a high frequency of GLRaV-1 in grapevines was detected with RT-PCR and representative isolates were sequenced. Taken together with the nucleotide comparisons, phylogenetic analysis grouped Turkish isolates into Group 2 as before reported by Alabi et al., (2011). Similarly, Elci (2019) reported that some Turkey isolates belong to Group 2. According to these results, there is only Group 2 among the Turkish isolates. In previous studies reported that the most divergent region was CPd2 while the lowest region was HSP7Oh among the GLRaV1 genes and GLRaV-1 genes have a high genetic variation and the CPd2 gene is the most variable gene (Alabi et al., 2011; Elçi, 2019).

As it was in the world and different regions of Turkey, GLRAV-1 was diagnosed at high levels in vineyards of Tokat province. The other GLRaV agents (GLRAV-3 GLRaV-2, 4 and 9 strain) were also diagnosed in vineyards of Tokat province. Existence of these disease agents even at quite low levels threatens the viticulture of the province. These disease agents are transmitted through different vectors, but the primary transmission material is scions taken from infected plants. In this sense, it is recommended that plant material to be used in grafting and the samplings to be used in vineyard establishments should definitely be composed of registered materials. The present survey revealed for the first time the occurrence of GLRaV-2, and -4 strain 9 on grapevines of Turkey. In conlclusion, viral diseases are among the most important problems and cause serious yield losses in viticulture.. Mostly preventive measures are taken against viral diseases and infections. Today, there aren't any control methods except for eradication and cultural measures against viruses. Therefore, early and reliable diagnosis of viruses with the use of modern techniques is a quite significant issue in the control of viral diseases (Onder et al., 2016). Early diagnosis of viral agents in a short time will allow producer to prevent infection and spread of these agents and thus will contribute to the prevention of resultant losses.

\section{CONFLICT OF INTEREST}

The authors declare no confict of interest.

\section{DECLARATION OF AUTHOR CONTRIBUTION}

KS: Survey and laboratory studies

ŞT: Planning the study, evaluation of analyzes, design of the article and writing of the article

\section{ACKNOWLEDGMENT}

This work funded by Gaziosmanpasa University Scientific Research Projects Division (BAP) coded 2018/52.

\section{REFERENCES}

Al Rwahnih, M., Dolja, V. V., Daubert, S., Koonin, E., \& Rowhani, A. (2011). Genomic and biological analysis of Grapevine leafrollassociated virus 7 reveals a possible new genus within the family Closteroviridae. Virus Research, 163(1), 302-309.

Alabi, O., Rwahnih, J., Karthikeyan, M. A., Poojari, G., Fuchs, S., Rowhani, M., \& Naidu, A. (2011). Grapevine leafroll associated virus 1 occurs as genetically diverse populations. Phytopathology, 101(12), 1446-1456.

Alknowni, R., Rowhani, A., Daubert, S., \& Golino, D. (2004). Partial characterization of a new ampelovirus associated with grapevine leafroll disease. Journal Plant Pathology, 86(2), 123-133.

Bertazzon, N., Borgo, M., Vanin, S., \& Angelini, E. (2010). Genetic variability and pathological properties of Grapevine leafrollassociated virus 2 isolates. European Journal of Plant Pathology, 127(2), 185-197.

Beuve, M., Sempé, L., \& Lemaire, O. (2007). A sensitive one-step realtime RT-PCR method for detecting Grapevine leafrollassociated virus 2 variants in grapevine. Journal of Virological Methods, 141(2), 117-124. 
Buzkan, N., Karadağ, S., Kaya, A., Baloğlu, S., Minafra, A., \& Ben-Dov, Y., (2012). Investigating the presence of mealybug species as vectors for viruses in grape growing areas in Turkey. Canadian Journal of Plant Pathology-Revue Canadienne de Phytopathologie, 34(2), 298-305.

Çelik, H. (2013). Türkiye bağciliğinda üretim hedefleri. Vizyon 2023 Bağcılık Çalıştayı, Tekirdağ Bağcılık Araştırma İstasyonu, Tekirdağ.

Çelik, H., Ağaoğlu, Y. S., Fidan, Y., Marasalı, B. \& Söylemezoğlu, G. (1998). Genel Bağcılık. Sunfidan A.Ş. Mesleki Kitaplar Serisi, Ankara.

Elçi, E. (2019). Genomic Variability and Recombination Analysis of Grapevine leafroll-associated virus-1 Isolates from Turkey. Journal of Agricultural Sciences, 25(3), 319-327

Erkan, S., Gümüş, M., Paylan, I. C. \& Sipahioğlu, H. M. (2011). Bitki Virüslerinin Tanılanmasında Kullanılan Serolojik Yöntemler. Elektronik Mikrobiyoloji Dergisi, 9(2), 35-49.

FAO. (2016). FAO-OIV FOCUS 2016. http://www.fao.org/3/a-i7042e.pdf. Access date: 18 MayIs 2019.

FAO. (2017). Crops datas. https://www.fao.org/faostat/en/\#data/QCL. Access date: 18 Mayıs 2019.

Ince, E., \& Yavuz, S. (2015). Current status of Grapevine leafroll associated viruses in East Mediterranean Region of Turkey. Proceedings of the 18th Congress of the International Council for the Study of Virus and Virus-like Diseases of the Grapevine, Ankara, Turkey.

Karadeniz, A., Yagcl, A., Topkaya, S., \& Yanar, Y. (2018). Serological Diagnosis of Several Grapevine Virus Agents in Tokat Province and District. Plant Protection Bulletin, 58(2), 103-110.

Kaya, A., \& Erilmez, S. (2014). Detection of Viruses in Aegean Region Grapevines. The Journal of Turkish Phytopathology, 43(13), 45-57.

Kumar, S., Stecher, G., Li, M., Knyaz, C., \& Tamura K. (2018). MEGA X: Molecular Evolutionary Genetics Analysis across computing platforms. Molecular Biology and Evolution, 35, 1547-1549.

Li, R., Mock, R., Huang, Q., Abad, J., Hartung, J., \& Kinard, G. (2008). A reliable and inexpensive method of nucleic acid extraction for the PCR-based detection of diverse plant pathogens. Journal of Virological Methods, 154(1-2), 48-55.

Ling, K. S., Zhu, H. Y. \& Gonsalves, D. (2004). Complete nucleotide sequence and genome organization of Grapevine leafrollassociated virus 3, type member of the genus Ampelovirus. Journal of General Virology, 85(7), 2099-2102.

Maliogka, V. I., Dovas, C. I. \& Katis, N. I., (2008). Generic and Species-Specific Detection of Viruses Belonging to an Evolutionary Distinct Lineage within the Ampelovirus Genus. Journal of Virological Methods, 154(1-2), 41-47.

Maree, H. J., Pirie, M. D., Bester, R., Oosthuizen, K., \& Burger, J. T. (2015). Phylogenomic analysis reveals deep divergence and recombination in an economically important grapevine virus. Public Library of Science 10(5), e0126819.

Martelli, G. P. (2014). Directory of Virus and Virus-Like Diseases of the Grapevine and Their Agents. Journal of Plant Pathology, 96(1), 1-136.

Martelli, G. P., Abou Ghanem-Sabanadzovic, N., Agranovsky, A. A., Al Rwahnih, M., Dolja, V. V., Dovas, C. I., Fuchs, M., Gugerli, P., Hu, J. S., Jelkmann, W., Katis, N. I., Maliogka, V. I., Melzer, M. J., Menzel, W., Minafra, A., Rott, M. E., Rowhani, A., Sabanadzovic, S., \& Saldarelli, P. (2012). Taxonomic revision of the family Closteroviridae with special reference to the Grapevine Leafroll Associated members of the genus Ampelovirus and the putative species unassigned to the family. Journal of Plant Pathology, 94, 7-19.

Martelli, G. P. (2017). An overview on grapevine viruses, viroids, and the diseases they cause. In B. Meng, G. P. Martelli, D. A. Golino, \& M. Fuchs (Eds.), Grapevine Viruses: Molecular Biology, Diagnostics and Management, Cham: Springer International Publishing, 31-46.

Martin, R. R., Eastwell, K. C., Wagner, A., Lamprecht, S., \& Tzanetakis, I. E. (2005). Survey for Viruses of Grapevine in Oregon and Washington. Plant Disease, 89(7), 763-766.

Moura, C. J. M., Fajardo T. V. M., Eiras, M., Silva, F. N., \& Nickel, O. (2018). Molecular characterization of GSyV-1 and GLRaV-3 and prevalence of grapevine viruses in a grape-growing area. Scientia Agricola, 75(1), 43-51.

Omeroglu, E. (2016). Determination of grapevine leafroll virus (GLRAVS) in some grape varieties in grapeyards in Tekirdağ province. MSc Thesis, Namık Kemal University Graduate School of Natural and Applied Sciences. Department of Plant Protection, Tekirdağ.

Onder, S. (2016). Detection and characterization of grapevine leafroll-associated viruses (GLRaVs) in Aegean Vineyards. PhD Thesis, Ege University. Graduate School of Natural and Applied Science, İzmir.

Onder, S., Paylan, I. C., \& Gümüş, M. (2016). Detection of Several Important Viral Agents by Real-time PCR in Aegean Vineyards. The Journal of Turkish Phytopathology, 45, 21-29. 
Türkmen, Y. (2014). The detection and prevalence of leafroll viruses in Turkish vineyard. MSc Thesis, Ankara University, Graduate School of Natural and Applied Science, Ankara.

Yakar, M. (2017). Molecular diversity of grapevine leafroll-associated virus-2 (glrav-2) in autocthonous Grapevine varities in eastern mediterranean and southeast anatolia regions. MSc Thesis, Kahramanmaraş Sütçü İmam Universty Graduate School of Natural and Applied Sciences, Kahramanmaraş. 